\title{
Observations on the Fauna and Constituents of an Estuarine Mud in a Polluted Area.
}

\author{
By
}

James H. Fraser, M.Sc.,

Department of Zoology, University of Liverpool.

With 2 Figures in the Text.

\section{Contents.}

PAGP

Introduction • $\cdot \quad \cdot \quad \cdot \quad \cdot \quad \cdot \quad \cdot \quad \cdot \quad \cdot \quad \cdot \quad \cdot \quad \cdot 69$

1. Description of the Areas and an Ecological Survey of the Fauna . . . . 71

2. An Analysis of the Constituents of the Grounds . . . . . . . . . 74

3. A Quantitative Analysis of the Molluscan Fauna . . . . . . . . $\quad$. 79

4. Correlation of the Fauna with Type of Ground and Tidal Level . $\quad$ - $\quad 81$

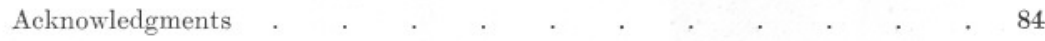

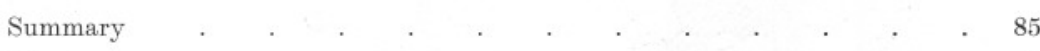

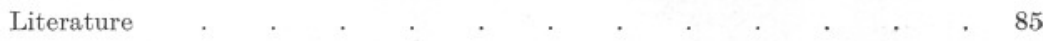

\section{INTRODUCTION.}

The estuarine mud dealt with in this paper lies on what is known as Dingle Beach, an area (the property of the Mersey Docks and Harbour Board) on the north bank of the Mersey Estuary between Liverpool and Garston. It lies in a region of much sewage pollution, as the river Mersey is used as an outlet for untreated sewage from the very densely populated districts on both of its banks; one large and one small sewer discharge on Dingle Beach itself. The river water in this area is of a fairly low salinity (samples taken at Low Water average $13 \%$ and at High Water $20 \%$ ), has a pH of about 7.9 and contains a certain amount of chemical pollution from the tanneries, chemical works and other industrial factories on its banks. In addition, the water contains large quantities of silt in suspension which prevents, to a large extent, the penetration of light and would tend to stop up the pores of certain types of animals (Sponges, Ascidians, etc.) and to eliminate Algæ.

Dingle Beach (Fig. 1) is $\frac{3}{4}$ mile in length and about 300 yards of shore are exposed at low water. Low-water mark of ordinary tides is about 


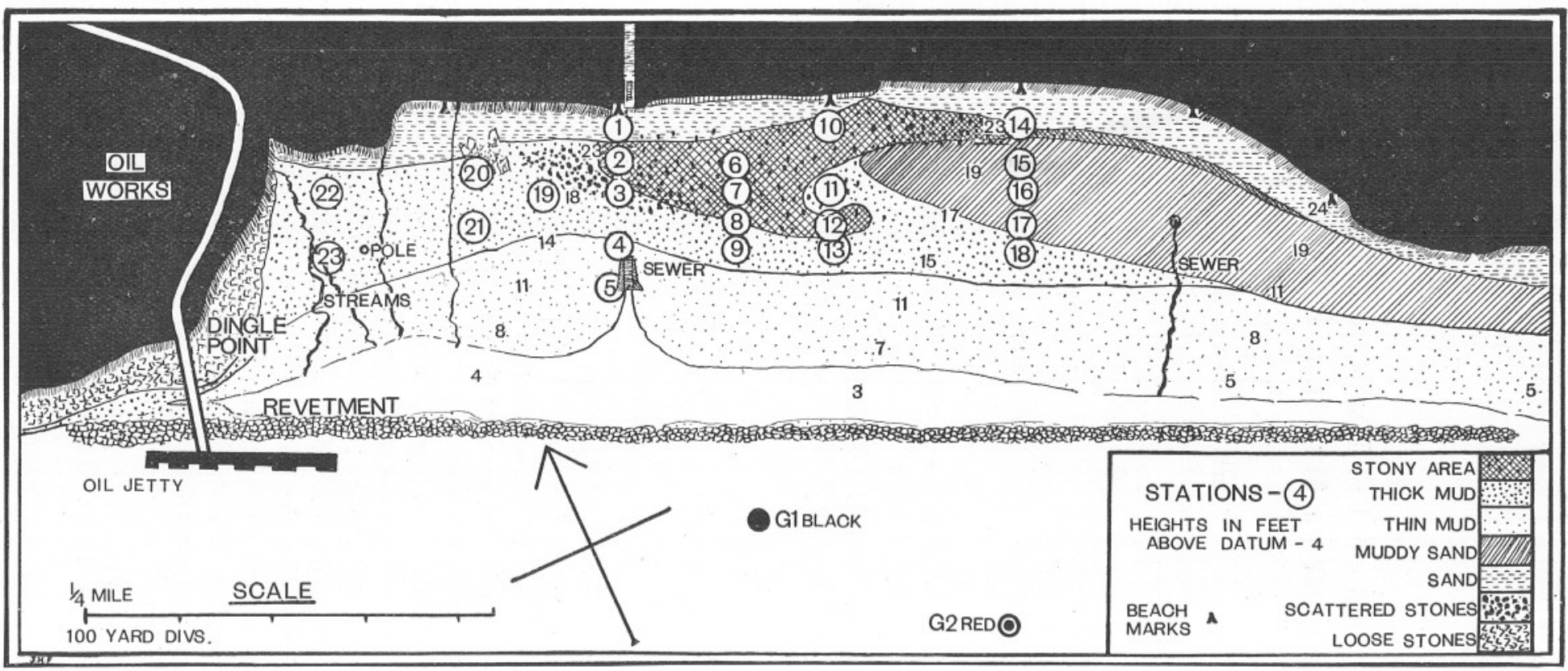

FIr. 1.-A map of Dingle Beach showing the different types of ground, the stations, tidal levels, etc. (The heights in feet above datum and general features taken from The Mersey Docks and Harbour Board chart of the River Mersey (1926). By permission.) 
4 feet above datum and high-water mark about 26 feet. The foreshore can be readily divided into several fairly distinct areas :-

I. A stony area near the centre of the beach with limits of 16 and 23 feet above datum.

II. An area of very thick and apparently stable mud on the west and south of the beach, not extending below half-tide level or above 23 feet.

III. An area of thin and unstable mud extending over the lower half of the shore, never extending above half-tide level.

IV. An area of muddy sand of a very similar tidal level to that of the thick mud area but at the eastern end.

V. A sandy area, the whole length of the beach above 23 feet.

These areas and their approximate boundaries and tidal levels are shown in Figure 1.

An attempt has been made to treat these areas from three standpoints :

1. An ecological survey of the fauna present.

2. An analysis of the constituents of the mud, sand, gravel and stones in the soil, to find the exact structure of the medium in which the fauna lives.

3. A quantitative analysis of the Molluscan fauna from a series of stations.

\section{Description of the Areas and an Ecological Survey of the FAuna.}

I. The Stony Area. (Limits of tidal level :-16-23 feet above datum.)

This area consists of shingle lying on a clay bed which is about 7-12 cm. below the surface. The larger stones are toward the surface, smaller ones below, grading into sand before reaching the clay, while the spaces between the larger stones near the surface are filled by a wet mud (Fig. 2). On the border of this area, most particularly to the west side (Fig. 1), are a few large scattered stones, surrounding each of which is usually to be found a small pool the size depending on the size of the stone concerned.

The stony area contains the most varied fauna of any part of the beach.

The following species are to be found :-

Clitellio arenarius O.F.M. In great abundance at the surface of the mud filling the spaces between the stones.

Nereis diversicolor O.F.M. In the gravel and coarse sand below the stones, fairly abundant (about 20 per sq. metre).

Mya arenaria $\mathrm{L}$. Extremely abundant but small. It is very significant that $(a)$ although Mya is so very prolific in this area it is almost absent on 
other parts of the beach, and that $(b)$ in places where the underlying clay bed lies deepest the Mya are largest. Specimens rarely reach $3.5 \mathrm{~cm}$. in length, those apparently showing two summers' growth average $1 \cdot 7 \mathrm{~cm}$. in February. In one small area where there is a sudden drop in the clay bed (<30 cm.) Mya reach $5 \cdot 0 \mathrm{~cm}$. (averaging $3 \cdot 2 \mathrm{~cm}$.). No large shells have been found cast up. The spat falls in late May (2-3 mm.).

Macoma balthica (L). Extremely abundant in the mud at the surface, but average only $1-1.5 \mathrm{~cm}$. in length. Both white and pink varieties are present in almost equal numbers and there does not seem to be any correlation between colour and either size or sex. The spat falls in late May and early June, a time similar to that given by Stephen (5) for Macoma in the Firth of Forth. This year, however (1932), small but definite quantities of spat ( $3 \mathrm{~mm}$.) were found in February.

Cardium edule L. Very small and infrequent, rarely reaching $1 \mathrm{~cm}$. in length even when showing 3 rings.

Mytilus edulis L. Occasional specimens showing up to 3 rings and measuring only $1.5 \mathrm{~cm}$. in length may be found attached to small stones; they are, as a rule, partly buried in the mud.

Hydrobia ulva (Pennant). Scattered over the surface but in no great quantity.

Littorina littorea (L). Abundant. They are to be found crawling over the surface of the area and settling on the larger drier stones. As many as 40 may be collected from a stone of barely a cubic foot. Specimens appear to be smaller towards the N.W. end of the area.

Littorina littoralis $(\mathrm{L})$. In a similar habitat to $L$. littorea but occurs only infrequently. Dead shells are common.

Carcinus manas (Pennant). Specimens up to $2 \mathrm{~cm}$. across the carapace are to be found occasionally amongst the stones.

Gammarus locusta (L). In a similar habitat to Carcinus.

Corophium volutator (Pallas). Infrequent, buried in the mud.

Balanus balanoides (L). Present on some of the larger stones.

Dead shells of Scrobicularia plana (Da Costa) exist. They are mostly broken and all have apparently been dead a long time.

A diagrammatic section through the stony area showing the distribution of fauna and constituents will be found in Figure 2, page 83 .

\section{The Area of Thick Mud. (14-23 feet above datum.)}

The layer of stiff mud covering this area varies from about $30-60 \mathrm{~cm}$. in depth and is jet-black just below the surface. The mud, although becoming distinctly wetter at the lower extremities of the area, is nevertheless quite stable as it is covered with a thick layer of diatoms, giving the mud a chocolate colour especially in spring and summer. Bright green patches occur in places marking the position of enormous numbers 
of Euglena limosa Gard. Mr. Ghazzawi (3) has identified the following diatoms from this area :-

Colletonema neglectum Thwaites; C. subcohørens Thwaites; Melosira nummuloides Kütz; Rhabdonema minutum Kütz; Achnanthes subsessilis Kütz; Shizonema smithii Ag; Licmophora lyngbgei (Kütz); Amphora cymbifirca Gregory; Synedra affinis Kütz; Pleurosigma quadratum Smith; P. fasciola (Kütz); Orthosira marina Smith (not living); Navicula bahusiensis Grun; Nitzchia tania Smith; N. sigma Smith.

The following species are to be found :-

Clitellio arenarius O.F.M. In great abundance at the surface.

Nereis diversicolor O.F.M. Very abundant at a depth from 10-20 cm. Occasionally on the surface. In and near the pools are to be found $N$. diversicolor of a vivid green colour resembling that of Eulalia viridis.

Mya arenaria L. Comparatively infrequent and small.

Macoma balthica (L). In immense numbers in the upper three or four centimetres of mud, and of a size similar to those in the stony area.

Cardium edule L. Specimens occur occasionally but are always small.

Littorina littorea (L). Plentiful toward high-water mark crawling on the surface of the mud, apparently browsing on diatoms. Skeletons of diatoms are numerous in the fæces.

Littorina littoralis (L). In a similar habitat to L. littorea but rare.

Hydrobia ulvo (Pennant). Scattered fairly thickly over parts of the area.

Corophium volutator (Pallas). Only occasional specimens.

\section{The Area of Thin Mud. (Below 14 feet above datum.)}

The mud covering the area below half-tide level is of a very thin and wet nature, on which it is impossible to walk. It is possible to investigate parts of the area by using the brickwork of the sewer as a foothold. The mud is very unstable and apparently contains little macroscopic life. A few Nereis diversicolor occur in the thicker parts, and where occasional large stones project out of the mud, straggling specimens of Balanus balanoides find attachment.

\section{The Area of Muddy Sand. (11-23 feet above datum.)}

In this area a layer of fairly clean sand lies on the surface, but removal of the upper centimetre reveals a muddy sand black in colour. The surface of the area is dotted with small holes which indicate the presence of Corophium volutator. Patches of diatoms and of Euglena limosa occur 
in places but are not so abundant nor as luxurious as those on the thick mud area. The following species occur :-

Corophium volutator (Pallas). In very great abundance living just below the surface.

Nereis diversicolor O.F.M. In no great abundance.

Mya arenaria $\mathrm{L}$. Infrequent and small.

Macoma balthica (L). Present, but in no great numbers.

Littorina littorea (L). Common on the borders of the stony area and comparatively big.

Littorina littoralis $(\mathrm{L})$. Occasionally only.

Dead shells of Scrobicularia plana occur also in this area.

\section{The Sandy Area near H.W. Mark. (Above 23 feet above datum.)}

This area, at and near high-water mark, consists of coarse, clean sand. The constituent particles are mostly between $350 \mu$ and $500 \mu$. The fauna is poor and consists of a few Littorina and Carcinus. No additional fauna is found by digging.

Stranded on the beach chiefly in summer may be found Aurelia aurita (L) and Pleurobrachia pileus (O.F.M.), while in the small pools Crangon vulgaris $\mathrm{L}$. is abundant. Liparis montagui (Donovan) and Gobius minutus Pallas are occasional.

\section{An Analysis of the Constituents of the Grounds.}

\section{The Stony Area.}

Mention has already been made (p. 71) of the structure of the stony area and the general arrangement of the constituents. (See also Fig. 2.) The exact analysis of the constituents was made in the following manner. The frame used in the quantitative analysis of the Mollusca (p. 79) was used to mark out a definite area (1/16 sq. metre) and the whole of the material in that area down to the clay bed placed in a canvas bag, the collector using his own judgment as to whether an individual stone on the border line would be taken or disregarded.

This material, on reaching the laboratory, was washed through a series of sieves with round holes of the following diameters $-5 \mathrm{~mm}$., $4.5 \mathrm{~mm}$., $4 \mathrm{~mm}$., $3.5 \mathrm{~mm}$., $3 \mathrm{~mm}$., $2.5 \mathrm{~mm}$., $2 \mathrm{~mm}$., $1.5 \mathrm{~mm}$., $1 \mathrm{~mm}$. and $0.75 \mathrm{~mm}$. Most of the material passing the last sieve was retained in a large vessel, but the silt was lost. The various grades were all dried separately and that retained on the first sieve graded by means of sieve plates with holes of 50,25 and $10 \mathrm{~mm}$. diameter; that passing the last sieve was sifted through gauges with square holes of 500,350 and $150 \mu$. 
Allen (1) grades material as follows :-

I. Stones. All inorganic material which will not pass through a 15-mm. sieve.

II. Coarse Gravel. Material left on a 5-mm. sieve.

III. Medium Gravel. Material left on a $2 \cdot 5-\mathrm{mm}$. sieve.

IV. Fine Gravel. Material left on a 1.5-mm. sieve.

V. Coarse Sand. Material left on a 1-mm. sieve.

VI. Medium Sand. Material left on a $0 \cdot 5-\mathrm{mm}$. sieve.

VII. Fine Sand. Passing 0.5-mm. sieve but which settles in one minute after stirring.

VIII. Silt. Remains in suspension at the end of one minute.

These terms, with the exception of the first, will be used here ; a 10-mm. sieve however is used as the defining mechanism for stones. Although Allen expresses the results as percentages of the total weight it was thought to be of more value to express results as volumes, this not being dependent upon the specific gravities of the various materials and as it is volume that is the biological factor concerned.

The volumes were obtained by the Archimedes principle, dry material being put into the water and all the air bubbles shaken out. Samples from two stations of the stony area are given (Table I), and as the amount of material used in each case is the same, "the figures are comparable without being reduced to percentages.

To complete the total volume of about 4500 c.c. $\left(25^{2} \times 7=4375\right)$ there is required (1) water, (2) silt, and (3) living material. In this last case it will readily be seen that 295 molluses found in this space will occupy an appreciable volume. $(295=1 / 16 \times 4720$ : Stn. 7 , Table VIII.)

A comparison of the two samples in Table I shows that although they compare very favourably, Station 6 (nearer high-water mark-Fig. 1) is of a slightly finer texture than Station 7 even although Station 6 contains stones above $5 \mathrm{~cm}$. diameter. There is a certain amount of selection in taking a sample as the collector naturally tends to avoid including any large stone.

Mud from between the stones was analysed by means of a Nobel's Elutriator. The apparatus had four separators of internal diameters at the widest parts of $6 \mathrm{~cm} ., 9.5 \mathrm{~cm} ., 13.5 \mathrm{~cm}$. and $17.5 \mathrm{~cm}$. approximately, and was run with a constant head of water of $106 \mathrm{~cm}$. $(34 \mathrm{~cm}$. stock and $72 \mathrm{~cm}$. siphon) and the outlet pipe drawn out to form a resistance. With the tap full open the elutriator discharged at approximately 600 c.c. per minute, the rate of flow at the widest parts of the separators was therefore $212.4 \mathrm{~mm}$., $84.6 \mathrm{~mm}$., $41.9 \mathrm{~mm}$. and $25.0 \mathrm{~mm}$. per minute. 


\section{TABLE I.}

\section{Results of Analysis (Stony Area).}

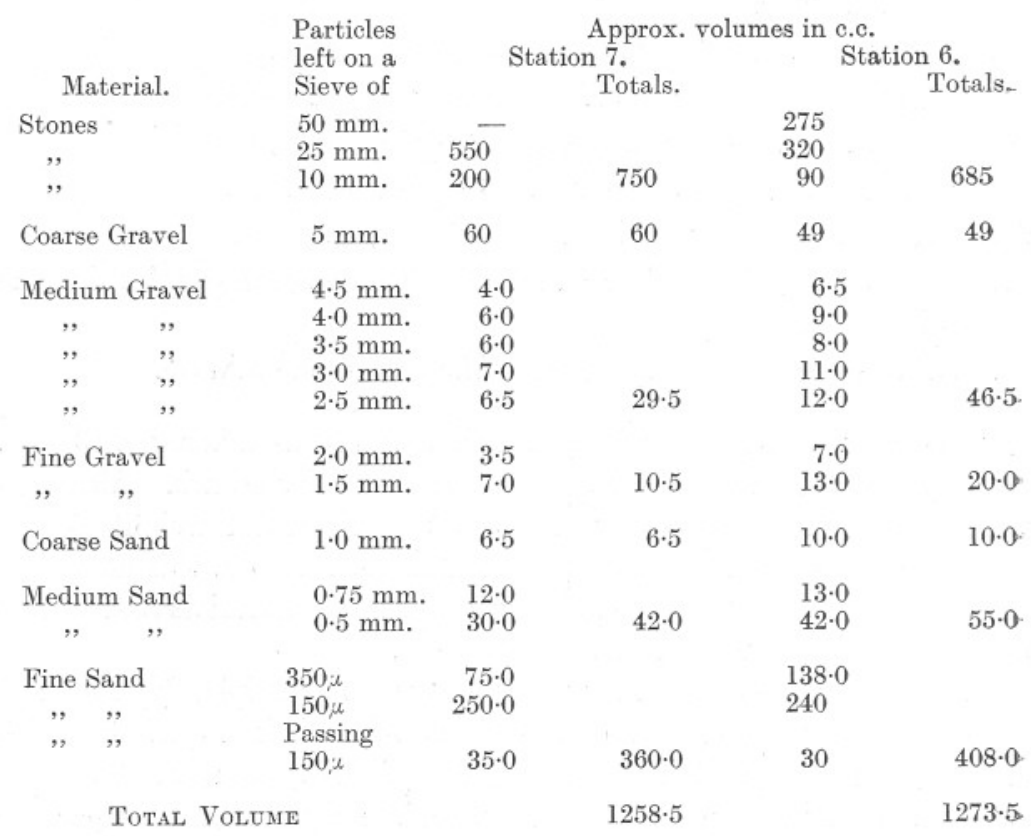

TABLE II.

Wet weight of sample 15.50 grams.

$\begin{array}{lcc}\text { Material. } & \text { \% of wet wt. } & \% \text { of dry wt. } \\ \text { Mud (wet) } & 100 & - \\ \text { " (dry) } & 73 \cdot 36 & 100 \\ \text { Water } & 26 \cdot 64 & \\ \text { lst separator } & 50 \cdot 71 & 69 \cdot 11 \\ \text { 2nd " } & 0 \cdot 44 & 0 \cdot 60 \\ \text { 3rd " } & 3 \cdot 83 & 5 \cdot 22 \\ \text { 4th " } & 1 \cdot 66 & 2 \cdot 32 \\ \text { Silt } & 8 \cdot 42 & 11 \cdot 48 \\ \text { Total } & 65 \cdot 06 & 88 \cdot 73 \\ \text { Error* } & 8 \cdot 30 & 11 \cdot 27\end{array}$

* The error represents a total error made by a combination of errors in :-

(1) Sampling (two samples not of identical consistency).

(2) Experimental error (including loss of material in transfer).

(3) A loss of silt from the elutriato:

(4) A loss of soluble salts. 
Material falling at a rate greater than the flow would be retained in its respective separator. Silt passes over. Measurements of the materials thus separated were found to be :-
(1) greater than $100 \mu$
(2) $60-100 \mu$
(3) $20-60 \mu$
(4) less than $20 \mu$

Two identical (as far as possible) portions of mud obtained by weighing to $0.01 \mathrm{gm}$. were treated, one being dried in a low-temperature oven and the other elutriated. The apparatus was started slowly and gradually increased to full speed. Almost all the silt came over together and was collected in jars and filtered. The sediments were dried and weighed.

Mud from amongst the stones gave the analysis given in Table II by this method.

It is really this mud rather than the stones and gravel that forms the medium in which the Macoma live. (See Fig. 2.)

\section{The Area of Thick Mud.}

Double samples of mud from this area were taken in identical glass tubes (two halves of a combustion tube) fitted with rubber bungs. The two mud samples were taken as close to each other as possible so that they might be considered of identical consistency. Analyses were made of the upper layer and of a layer below $3 \mathrm{~cm}$. depth. The samples were treated in the same way as the mud from the stony area (see above). The following results given in Table III were obtained.

\section{TABLE III.}

\begin{tabular}{|c|c|c|c|c|}
\hline \multirow[b]{2}{*}{ Material. } & \multicolumn{2}{|c|}{$\begin{array}{l}\text { Depth } 0-2.5 \mathrm{~cm} . \\
\text { Wet wt. of sample } 19.04 \mathrm{gm} .\end{array}$} & \multicolumn{2}{|c|}{$\begin{array}{l}\text { Depth } 3-5.5 \mathrm{~cm} . \\
\text { Wet wt. of sample } 18.07 \mathrm{gm}\end{array}$} \\
\hline & $\%$ of wet wt. & $\%$ of dry wt. & $\%$ of wet wt. & $\%$ of dry wt. \\
\hline Mud (wet) & 100 & - & 100 & - \\
\hline,$\quad$ (dry) & $65 \cdot 32$ & 100 & $60 \cdot 87$ & 100 \\
\hline Water & $34 \cdot 68$ & - & $39 \cdot 13$ & - \\
\hline 1st separator & $38 \cdot 92$ & $58 \cdot 76$ & $18 \cdot 16$ & $29 \cdot 82$ \\
\hline 2 nd & $12 \cdot 52$ & $18 \cdot 90$ & $10 \cdot 54$ & $17 \cdot 32$ \\
\hline $3 \mathrm{rd}$ & $2 \cdot 81$ & $4 \cdot 35$ & $4 \cdot 46$ & $7 \cdot 23$ \\
\hline 4th & $5 \cdot 70$ & $8 \cdot 61$ & $2 \cdot 67$ & $4 \cdot 39$ \\
\hline Silt & $0 \cdot 86$ & $1 \cdot 32$ & $8 \cdot 38$ & $13 \cdot 77$ \\
\hline Total & $60 \cdot 81$ & $91 \cdot 94$ & $44 \cdot 21$ & $72 \cdot 53$ \\
\hline Error & $4 \cdot 51$ & 8.06 & $16 \cdot 66$ & $27 \cdot 47$ \\
\hline
\end{tabular}

The large error in the second sample is due to three small stones present in the first tube giving the mud a greater dry weight. It will be seen that 
the lower layer contains more water and much more silt than the upper a result to be expected from the appearance of the sample in the tube. The samples are taken from Station 11.

\section{The Area of Thin Mud.}

The results of an analysis of a sample from Station 4 at the border of the thin and thick muds is given in Table IV, and one from the really thin mud (Station 5) is given in Table V.

TABLE IV.

\begin{tabular}{|c|c|c|c|c|}
\hline & $\begin{array}{c}\text { Depth } \\
\text { Wet wt. of } s a\end{array}$ & $\begin{array}{l}-2.5 \mathrm{~cm} . \\
\text { ple } 20.32 \mathrm{gm} .\end{array}$ & $\begin{array}{r}\text { Depth } 3 \\
\text { Wet wt. of sar }\end{array}$ & $\begin{array}{l}-5.5 \mathrm{~cm} . \\
\text { aple } 14.28 \mathrm{gm} .\end{array}$ \\
\hline Material. & $\%$ of wet wt. & $\%$ of dry wt. & $\%$ of wet wt. & $\%$ of dry wt. \\
\hline Mud (wet) & 100 & - & 100 & - \\
\hline ,' (dry) & $54 \cdot 24$ & 100 & $58 \cdot 64$ & 100 \\
\hline Water & $45 \cdot 76$ & - & $41 \cdot 36$ & \\
\hline lst separator & $24 \cdot 14$ & $44 \cdot 50$ & $26 \cdot 93$ & $45 \cdot 76$ \\
\hline 2nd & $6 \cdot 43$ & $11 \cdot 84$ & $10 \cdot 58$ & $18 \cdot 05$ \\
\hline 3rd & $4 \cdot 44$ & $8 \cdot 19$ & $5 \cdot 03$ & $8 \cdot 58$ \\
\hline 4th & $4 \cdot 89$ & $9 \cdot 01$ & $6 \cdot 77$ & $11 \cdot 55$ \\
\hline Silt & $6 \cdot 69$ & $12 \cdot 34$ & $3 \cdot 25$ & $5 \cdot 54$ \\
\hline Total & $46 \cdot 59$ & $85 \cdot 88$ & $52 \cdot 56$ & $89 \cdot 48$ \\
\hline Error & $7 \cdot 65$ & $14 \cdot 12$. & $6 \cdot 08$ & $10 \cdot 52$ \\
\hline
\end{tabular}

\section{TABLE V.}

Wet weight of sample $9 \cdot 73$ grams.

$\begin{array}{ccc}\text { Material. } & \% \text { of wet wt. } & \% \text { of dry wt. } \\ \text { Mud (wet) } & 100 & - \\ \text {, (dry) } & 27.97 & 100 \\ \text { Water } & 72.03 & - \\ \text { lst separator } & \text { nil } & \text { nil } \\ \text { 2nd ,, } & 0.42 & 1.51 \\ \text { 3rd ," } & 2.56 & 9 \cdot 13 \\ \text { 4th ", } & 5 \cdot 34 & 19.09 \\ \text { Silt } & 19.64 & 70.23 \\ \text { Total } & 27.96 & 99.96 \\ \text { Error } & 0.01 & 0.04\end{array}$

IV. The Area of Muddy Sand.

This sand, from a glance at the sample in the tube, appears to be coarser and much freer from silt than the other areas. Table VI shows the results of an analysis from Station 16. 
TABLE VI.

Wet weight of sample 21.59 grams.

$\begin{array}{ccc}\text { Material. } & \text { \% of wet wt. } & \% \text { of dry wt. } \\ \text { Mud (wet) } & 100 & - \\ \text { " (dry) } & 66.45 & 100 \\ \text { Water } & 33.55 & - \\ \text { lst separator } & 47 \cdot 30 & 71 \cdot 19 \\ \text { 2nd , } & 9 \cdot 09 & 12.99 \\ \text { 3rd ", } & 1.04 & 1.57 \\ \text { 4th ", } & 6 \cdot 34 & 9.55 \\ \text { Silt negligible } & \text { negligible } \\ \text { Total } & 63.77 & 95.30 \\ \text { Error } & 2.68 & 4.70\end{array}$

V. The High-Water Zone.

The analysis of the clean sand at high-water mark (Station 1) gives a result to be expected. (Table VII.) Sieving a sample of sand shows the particles to be mostly between $350 \mu$ and $500 \mu$ in size.

\section{TABLE VII.}

Wet weight of sample $15 \cdot 23$ grams.

$\begin{array}{ccc}\text { Material. } & \% \text { of wet wt. } & \% \text { of dry wt. } \\ \text { Sand (wet) } & 100 & - \\ \text { " (dry) } & 81.90 & 100 \\ \text { Water } & 18 \cdot 10 & - \\ \text { 1st separator } & 79 \cdot 09 & 96.56 \\ \text { 2nd , } & 0 \cdot 31 & 0.38 \\ \text { 3rd ", } & - & - \\ \text { 4th ", } & - & - \\ \text { Silt } & - & - \\ \text { Total } & 79.40 & 96.94 \\ \text { Error } & 2.50 & 3.06\end{array}$

3. A Quantitative Analysis of the Molluscan Fauna.

The method of estimating the numbers of molluses by marking out a definite area and sieving the contents was adopted here. To mark the area, a square wooden frame was used with internal measurements of $25 \mathrm{~cm}$. and $7.5 \mathrm{~cm}$. depth. The sieve was a wire framework with square holes $2.5 \mathrm{~mm}$. across. In the case of the stony area where it was impossible 


\section{TABLE VIII.}

Comparison of the Molluscan Fauna in Different Grounds at Similar Tidal Levels.

$$
\begin{aligned}
& \text { NUMBERS OF MOLLUSCS PER SQUARE METRE OF SURFACE. } \\
& 25 \text { feet } \quad \text { Stn. 1. Sand. } \\
& 23 \text { feet }
\end{aligned}
$$

20 feet

$$
\begin{array}{crlrrrrr}
\text { Stn. 20. Mud (with stones). } & \multicolumn{3}{r}{\text { Stn. 2. }} & \multicolumn{2}{c}{\text { Stony. }} \\
\text { L.la } & 0 & \text { L.ls } & 0 & \text { L.la } & 112 & \text { L.ls } & 0 \\
\text { M.a } & 128 & \text { M.b } & 960 & \text { M.a } & 48 & \text { M.b } & 576 \\
\text { C.e } & 0 & \text { M.e } & 0 & \text { C.e } & 0 & \text { M.e } & 0
\end{array}
$$

18 feet

Average of Stn. 19 and

$$
\begin{aligned}
& \text { 22. Thick Mud. } \\
& \text { L.la } 0 \text { L.ls } 0 \\
& \text { M.a } \quad 72 \text { M.b } 5928
\end{aligned}
$$

16 feet

Stn. 21. Thick Mud.

$$
\begin{array}{lrlr}
\text { L.la } & 0 & \text { L.ls } & 0 \\
\text { M.a } & 64 & \text { M.b } & 5264 \\
\text { C.e } & 16 & \text { M.e } & 0
\end{array}
$$

15 feet

$$
\begin{aligned}
& \text { Stn. 23. Thick Mud } \\
& \text { with fresh water. } \\
& \text { L.la } 0 \text { L.ls } \\
& \text { M.a } \quad 0 \quad \text { M.b } 112
\end{aligned}
$$

14 feet

Stn. 4. Border of Thick and Thin Muds.

$$
\begin{array}{lrlr}
\text { L.la } & 0 & \text { L.ls } & 0 \\
\text { M.a } & 16 & \text { M.b } & 372 \\
\text { C.e } & 48 & \text { M.e } & 0
\end{array}
$$

11 feet

Stn. 5. Thin Mud

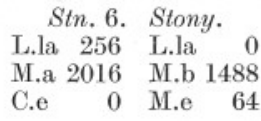

Stn. 6. Stony.

L.la 256 L.la 0

M.a 2016 M.b 1488

C.e 0 M.e 64

L.ls $=$ Littorina littoralis.

M. $=$ Macoma balthica.

M.e $=$ Mytilus edulis.

Stn. 10. Gravel with mud. Stn. 14. Gravel.

$$
\begin{array}{lrlrlrlr}
\text { L.la } & 272 & \text { L.ls } & 0 & \text { L.la } & 16 & \text { L.ls } & 0 \\
\text { M.a } & 32 & \text { M.b } & 560 & \text { M.a } & 0 & \text { M.b } & 208 \\
\text { C.e } & 0 & \text { M.e } & 0 & \text { C.e } & 0 & \text { M.e } & 0
\end{array}
$$

Stn. 7. Stony.

L.la 0 L.ls 0

M.a 544 M.b 4176

C.e 0 M.e

Stn. 8. Thick Mud with a few slones.

$\begin{array}{llll}\text { L.la } & 516 & \text { L.ls } & 16\end{array}$

M.a 434 M.b 2044

C.e 0 M.e 0

Stn. 9. Thick Mud.

L.la $\quad 0$ L.ls 0

Stn. 11. Thick Mud.

L.la $\quad 48$ L.ls $\quad 16$

M.a 336 M.b 2192

C.e 0 M.e 0

Stn. 12. Stony.

L 288 L.ls 48

M.a 3872 M.b 4736

Stn. 15. Muddy Sand.

L.la 0 L.ls 0

M.a $\quad 0$ M.b 848

C.e 16 M.e 0

Stn. 13. Thick Mud with a few stones.

Stn. 16. Muddy Sand. L.la 0 L.ls 0 M.a 32 M.b 1827 C.e 0 M.e 0

C.e 16 M.e near Sewer.

$$
\text { nil. }
$$


to insert the frame, as in the mud or sand, it was held as firmly as possible until the stones on the border-line had been picked out by hand. Sieving was a laborious task as it was impracticable to reach the river and the pools on the shore were never more than a couple of inches in depth.

The molluscs were then picked out of the sieve and counted, only living ones being taken; dead and broken shells were ignored.

The stations from which the counts were made are shown in Figure 1. They have been so arranged that correlation can be made between stations in the same area but of different tidal levels, and between stations of the same tidal level but in different areas. Each count is multiplied by 16 to give the number which would be taken from a square metre of similar ground. The results are given in Table VIII and are arranged so that these correlations can be easily made out. The table is discussed in the following section.

In addition to those molluses mentioned in Table VIII, Hydrobia ulva (which passed through the sieve) was found to be most abundant at Stations 19 and 21. One living specimen of Scrobicularia plana was found near Station 20.

\section{Correlation of the Fauna with Type of Ground and Tidal Level.}

The correlation of the fauna with both the type of ground and tidal level is expressed in Tables VIII and IX. Table VIII shows the relationship of the various stations and the actual fauna at each, with both tidal level and type of ground, while Table IX shows the comparison of average numbers of molluses in each area with the results of the analysis of the ground constituents.

Although the absence of macrofauna at Station 1 is almost certainly due to tidal level, that at Station 5 must be due to the thin mud, a medium of waterlogged silt which would choke the breathing apparatus of most animals.

Mya arenaria seems to be associated with stones and is found in numbers only in the stony area and stations near the border (Stns. 9, 11, 13, 19, 20). The mean figure given for the stony area (Table IX) is 502 per square metre, but is increased to 1716 per sq. metre if the high-water Stations, 2, 10 and 14, are omitted. This latter figure gives a more accurate idea of their abundance. Their abundance increases from high-water mark towards a lower tidal level ( $c f$. Stn. 10 with 32 and Stn. 12 with 3872 per sq. metre) and shows a marked decrease in different areas at the same tidal level. $C f$. Station 12 (stony area), 3872: Station 17 (muddy sand), 0 : NEW SERIES.-VOL. XVIII. NO. 1. MAY, 1932. 
Station 21 (thick mud), 64. Their small size (p. 72) may be attributed to any or all of the following factors:-

1. Fairly high tidal level. There are no stony areas near low-water mark. Size as well as numbers increase in the area towards lowtidal levels.

2. Shallowness of available ground. Larger specimens are found in small areas where the clay bed lies deeper.

3. Shortage of food through overcrowding.

4. Low salinity $(13 \%)$.

5. Presence of a thick mud through which their siphons have to pass (Fig. 2).

\section{TABLE IX.}

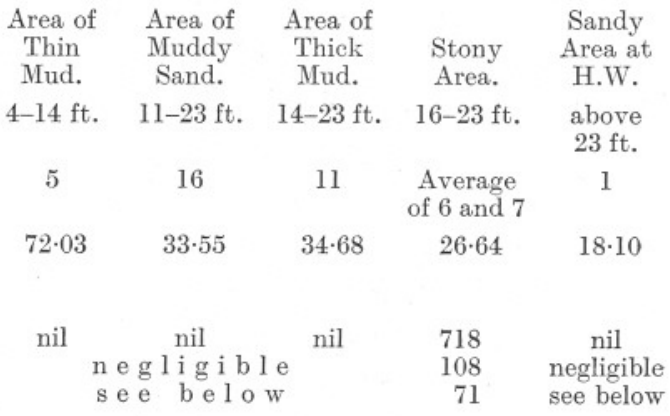

Limits of Tidal Level.

L.W. (ordinary tide) $=4$ feet.

H.W. (ordinary tide) $=26$ feet.

Data from Stn.

Water $\%$ wet weight

see below

Volume in c.c. per $625 \mathrm{sq}$. cm.

Stones

Gravel

Sand

Analysis of substance by elutriation (in the case of the stony area, of the mud from between the stones). Results expressed as \% dry weight.

Grade 1 above $100 \mu$

Grade 2 60-100 $\mu$

Grade $320-60 \mu$

Grade 4 below $20 \mu$

Silt

Mean No. per sq. metre of :

Mya arenaria

Macoma balthica

Cardium edule

Mytilus edulis

Littorina littorea

Littorina littoralis

$\begin{array}{rrrl}71 \cdot 19 & 58 \cdot 76 & 69 \cdot 11 & 96 \cdot 56 \\ 12 \cdot 99 & 18 \cdot 90 & 0 \cdot 60 & 0 \cdot 38 \\ 1 \cdot 57 & 4 \cdot 35 & 5 \cdot 22 & \text { nil } \\ 9 \cdot 55 & 8 \cdot 61 & 2 \cdot 32 & - \\ \text { nil } & 1 \cdot 32 & 11 \cdot 48 & - \\ & & & \\ 11 & 200 & 502 & 0 \\ 1030 & 3071 & 1443 & 0 \\ 5 & 6 \cdot 4 & 2 & 0 \\ 0 & 0 & 14 & 0 \\ 0 & 11 \cdot 2 & 162 & 0 \\ 0 & 3 \cdot 2 & 8 & 0\end{array}$

It is significant that spat of Mya $(<3 \mathrm{~mm}$.) may be found in quantity on all areas of the beach in late May, but it disappears in June on all but favourable grounds.

Macoma balthica is abundant wherever there is thick mud but becomes less so as this changes either to sand or to thin mud [ $c f$. Stn. 9 (thick mud), 3744: Stn. 4 (border of the thin mud), 372: Stn. 17 (border of muddy sand), 416]. The mud between the stones (Fig. 2) may be quite as good a 
medium for Macoma as the thick mud, for it is possible that a square metre containing stones with 1443 specimens might contain as many Macoma per actual unit of mud as the latter (homogeneous mud) with 3071 individuals. Numbers increase towards low-water mark (cf. Stns. 20 and 21). The restriction in sandy areas may be due to a large extent to the absence of sufficient food material on these areas as the diatoms and Euglena are mostly confined to the mud. It should be noted, however, that even in sandy areas (Stns. 15, 16 and 17) the numbers of Macoma are large compared with 150-200 per sq. metre

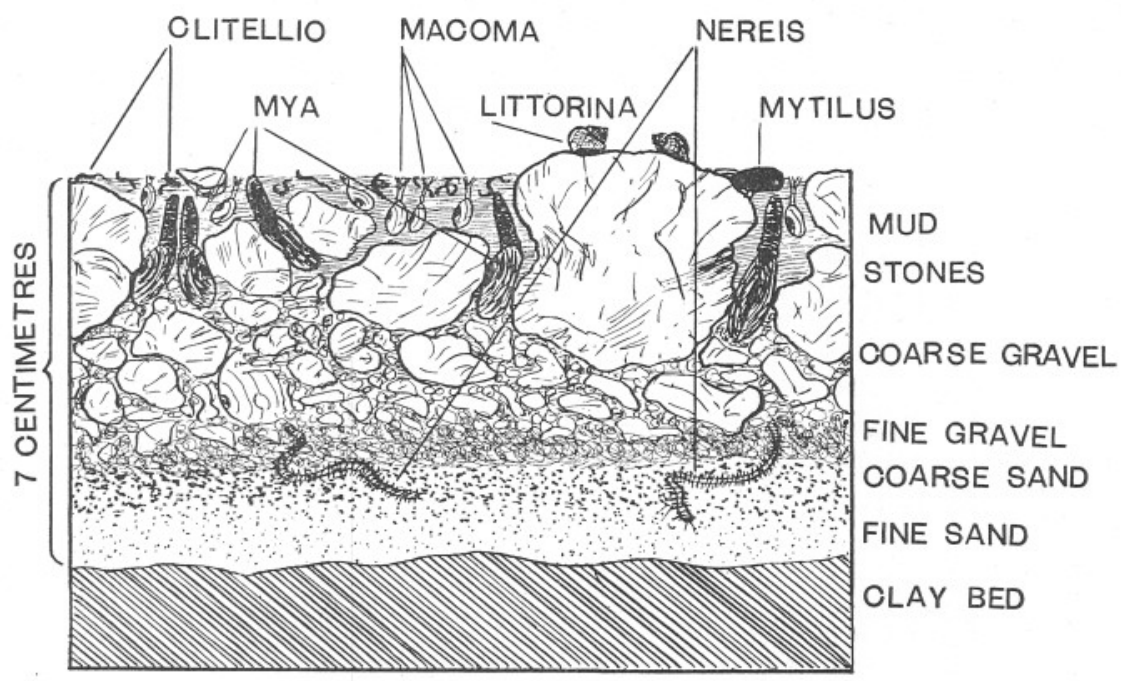

FIG. 2,-A diagrammatic section through a typical part of the stony area to show the relationships of the various constituents and the fauna.

given as a maximum for the same species in a typical area by Stephen (5) or with 20 given by Petersen (4) as typical of a Macoma community.

Cardium edule, generally considered as a co-partner with Macoma balthica on a muddy shore (Stephen, 6 ; Petersen, 4), is here very poorly represented. Stephen (6) notes that Cardium is usually found nearer low water than is Macoma, a statement that is to an extent borne out by examples from Dingle in that Cardium is most common at Stations 9, 12, 13 and 21. Specimens, however, are small (p. 72) and are obviously in an unsuitable habitat. They are in fairly equal numbers in the muddy sand and thick mud.

Mytilus edulis is much dwarfed and only found in the stony area (Table IX). The mud is probably the cause of its small size.

Littorina littorea is abundant in those areas where it may browse on diatoms in the absence of larger algæ, and at the same time benefit by 
the holdfast provided by the stones. Nereis diversicolor and Clitellio arenarius are in their natural habitat. Corophium thrives well in the muddy sand, only occasional though not noticeably stunted ones occur in other areas. The other species with one exception do not require special mention. Scrobicularia plana must at one time have been common on Dingle Beach but has apparently almost completely died out; shells, although abundant, seem to be all old and worn and only one living specimen has been found (p. 81).

Increase in the population of the neighbourhood during late years has given rise to a big increase in sewage and hence to corresponding increase in silt deposition (2). It is reasonable to suppose that the bulk of the silt has been laid down quite recently (the opinion of those residing in the area tends to support the hypothesis) and in such a way the dying out of Scrobicularia might possibly be explained, though too much stress should not be laid on this point as there is the possibility that Scrobicularia is still present, deep enough in the mud to have, as yet, escaped detection.

The importance of sewage in the river must be emphasised, as sewage products not only provide abundant inorganic salts permitting a luxurious growth of diatoms which, with bacteria, form directly or indirectly the food of almost every living thing on the beach, but that it is also the probable cause of the deposition of silt which has made the foreshore the type that it is (2).

Dingle Beach, from the above characters, can be described as a Macoma community but differing from the typical community, "d," as described by Petersen (4) in the excessive numbers of molluses present, and in the absence of forms such as Arenicola. Petersen's community, however, was below low-water mark, although that alone would not account for the difference. Although both Stephen (5) and Petersen (4) describe their grounds as "muddy" it seems probable that in consistency theirs will more closely resemble the muddy sand of Dingle than the other areas. No analysis is given by either.

\section{ACKNOWLEDGMents.}

I am indebted to Prof. Orton for his continued aid and advice in the carrying out of this survey; to Mr. Ghazzawi for the identification of the diatoms, to the Dept. of Oceanography for the use of the sieves and to the Mersey Docks and Harbour Board for permission to work on the beach, and for permission to reproduce in Figure 1 the heights in feet above datum, etc., given in their chart of the River Mersey (1926). 


\section{SUMMARY.}

1. An ecological survey of the fauna of Dingle Beach, Mersey Estuary, has been made.

2. A detailed analysis of the constituents of the mud, sand and gravel is given.

3. A quantitative analysis of the Molluscan fauna from a series of stations has been made.

4. Type of ground and fauna at different tidal levels are correlated. Mya arenaria is only found in abundance where there are stones. Macoma balthica is abundant wherever there is thick mud.

5. Dingle Beach is a type of Macoma community but differing markedly from the typical community described by Petersen as "d."

6. The importance of sewage in producing silt and the part played by sewage in the food chain are discussed.

\section{LITERATURE.}

1. Allen, E. J. On the Fauna and Bottom Deposits near the ThirtyFathom Line from the Eddystone Grounds to Start Point. Jour. Mar. Biol. Assoc., N.S., Vol. V, No. 4, June, 1899.

2. Baly, E. C. C. Properties of Sewage Colloids. Trans. Faraday Soc., Vol. XXVII, Pt. 5, May, 1931.

3. Ghazzawi, F. M. Unpublished records.

4. Petersen, C. G. J. A Survey of the Work done in connection with Valuation of the Danish Waters from 1883-1917. Rep. XXV. Danish Biological Station, 1918.

5. Stephen, A. C. Notes on the Biology of Certain Lamellibranchs on the Scottish Coast. Jour. Mar. Biol. Assoc., N.S., Vol. XVII, No. 2, 1931.

6. Stephen, A. C. Studies on the Scottish Marine Fauna: The Fauna of the Sandy and Muddy Areas of the Tidal Zone. Trans. Roy. Soc. Edin., Vol. LVII, Pt. II (No. 14), July, 1929. 
